\title{
PENGARUH CLOSE ENVIRONMENTAL FACTORS TERHADAP ENTREPRENEURIAL INTENTIONS DIMEDIASI OLEH INDIVIDUAL ENTREPRENEURIAL ORIENTATION
}

\author{
Della Monica dan Andi Wijaya \\ Program Studi Manajemen Fakultas Ekonomi Universitas Tarumanagara, Jakarta \\ Email: dellamonica20@gmail.com
}

\begin{abstract}
The purpose of this study was to examine whether the close environmental factors near students influenced their entrepreneurial intentions and was mediated by individual entrepreneurial orientation in students of the Management Department, Faculty of Economics and Business, Tarumanagara University. Using descriptive research methods processed with SmartPLS 3.3.2. The number of samples used in the study were 121 student respondents who had taken entrepreneurship courses. The results showed that individual entrepreneurial orientation mediated the relationship between environmental factors near students and entrepreneurial intentions, but the stigma of entrepreneurial failure had no effect on entrepreneurial intentions.
\end{abstract}

Keywords: Close Environmental Factors, Closer Valuation of Entrepreneurship, Closer Stigma of Entrepreneurial Failure, Individual Entrepreneurial Orientation, and Entrepreneurship Intentions.

Abstrak: Tujuan dari penelitian ini adalah untuk menguji apakah faktor lingkungan dekat mahasiswa berpengaruh terhadap niat berwirausaha mereka dan di mediasi oleh orientasi kewirausahaan individu pada mahasiswa/i Jurusan Manajemen Fakultas Ekonomi dan Bisnis Universitas Tarumanagara. Menggunakan metode penelitian deskriptif yang diolah dengan SmartPLS 3.3.2. Jumlah sampel yang digunakan dalam penelitian sebanyak 121 responden mahasiswa yang telah mengambil mata kuliah kewirausahaan. Hasil penelitian menunjukan bahwa orientasi kewirausahaan individu memediasi hubungan antara faktor lingkungan dekat mahasiswa dengan niat berwirausaha, tetapi stigma tentang kegagalan kewirausahaan tidak berpengaruh terhadap niat berwirausaha.

Keywords: Faktor Lingkungan Dekat, Penilaian Yang Lebih Dekat Tentang Kewirausahaan, Stigma Yang Lebih Dekat Tentang Kegagalan Kewirausahaan, Orientasi Kewirausahaan Individu, dan Niat Berwirausaha.

\section{LATAR BELAKANG}

Kewirausahaan memiliki peran penting dalam memajukan perekonomian suatu negara, sehingga diharapkan setiap warga negara harus memiliki niat untuk berwirausaha (Dewi dan Nurcaya, 2017). Proses kewirausahaan menuntut kemauan untuk mengambil resiko dengan penuh perhitungan sehingga dapat mengatasi rintangan untuk mencapai kesuksesan yang diharapkan (Sumadi dan Sulistyawati, 2017). Untuk mengembangkan usaha baru, penting untuk mamahami tentang apa yang membuat seseorang menjadi wirausaha. Hal ini disebabkan fakta bahwa kewirausahaan merupakan proses kompleks yang melibatkan kognisi kewirausahaan dan tindakan kewirausahaan (Koe, 2016). Kewirausahaan juga merupakan perilaku yang disengaja dan terencana (Koe, 2016). 
Oleh karena itu, menjadi menarik untuk mengetahui bagaimana elemen kognitif lingkungan dan dampaknya terhadap entrepreneurial intentions, selain bagaimana individual entrepreneurial orientation mewakili peran determinan yang membentuk hubungan ini. Pertama, untuk menganalisis hubungan langsung dari valuation of entrepreneurship dan stigma of entrepreneurial failure di lingkungan dekat mahasiswa dan bagaimana individual entrepreneurial orientation memainkan peran penting dalam membentuk hubungan tersebut. Kedua, menghubungkan dua konstruk yang divalidasi secara luas dan membuktikan hubungan yang mungkin ada antara orientasi dan niat sebenarnya dari mendirikan bisnis. Ketiga, terlepas dari kontribusi yang luas dari entrepreneurial orientation terhadap studi kewirausahaan, konstruksi individual entrepreneurial orientation belum sepenuhnya diteliti dalam studi entrepreneurial intentions. Membuat hubungan antara dua konstruksi yang divalidasi secara luas dan untuk membuktikan hubungan yang mungkin ada antara orientasi dan maksud sebenarnya dari mendirikan sebuah bisnis. Selain itu, individual entrepreneurial orientation jarang ditujukan untuk memverifikasi efek interaksi (Martins dan Perez, 2019). Tujuan penelitian ini adalah untuk mengetahui:

a. Apakah terdapat hubungan antara Closer Valuation of Entrepreneurship dengan Entrepreneurial Intentions

b. Apakah terdapat hubungan antara Closer Stigma of Entrepreneurial Failure dengan Entrepreneurial Intentions

c. Apakah terdapat hubungan antara Individual Entrepreneurial Orientation dengan Entrepreneurial Intentions

d. terdapat hubungan antara Closer Valuation of Entrepreneurship dengan Individual Entrepreneurial Orientation

e. Apakah terdapat hubungan antara Closer Valuation of Entrepreneurship dengan Entrepreneurial Intentions yang dimediasi oleh Individual Entrepreneurial Orientation

f. Apakah terdapat hubungan antara Closer Stigma of Entrepreneurial Failure dengan Individual Entrepreneurial Orientation

g. Apakah terdapat hubungan antara Closer Stigma of Entrepreneurial Failure dengan Entrepreneurial Intentions yang dimediasi oleh Individual Entrepreneurial Orientation

\section{KAJIAN TEORI}

Beberapa model dengan dasar kognitif telah digunakan untuk menjelaskan Entrepreneurial Intentions (Martins dan Perez, 2019) misalnya, Shapero's Model Of The Entrepreneurial Event (SEE) oleh Shapero dan Sokol (1982) dan The Theory Of Planned Behavior (TPB) oleh Ajzen (1991) merupakan model yang paling banyak diadopsi dalam penelitian Entrepreneurial Intentions. Kedua model menganggap bahwa lingkungan sosial berperan sebagai kunci penentu aktivitas kewirausahaan. Model yang dikembangan oleh Shapero dan Sokol (1982), lingkungan sosial dibingkai dalam faktor kontekstual yang interaksinya mempengaruhi persepsi bahwa seseorang memiliki niat untuk mendirikan usaha baru. Dengan demikian, tanggapan individu terhadap faktor kontekstual bergantung pada keinginan yang dirasakan, yaitu daya tarik pribadi untuk memulai bisnis dan pada kelayakan yang dirasakan, yang menunjukkan ukuran persepsi kapasitas pribadi untuk menciptakan bisnis. Model Ajzen (1991) menjelaskan bahwa faktor kontekstual mempengaruhi entrepreneurial intentions, melalui sikap terhadap perilaku tertentu. Sikap ini terdiri dari tiga komponen, yaitu kontrol perilaku yang dipersepsikan, sikap terhadap perilaku, dan normanorma sosial. 
Kaitan Closer Valuation of Entrepreneurship (CVE) dan Entrepreneurial Intentions (EI). Tekanan sosial dari lingkungan dekat dapat menjadi pemicu berkembangnya karir kewirausahaan (Iakovleva et al., 2011). Misalnya, pendapat keluarga dapat mempengaruhi fenomena wirausaha yang terkenal dalam hal pengakuan peluang, pencapaian sumber daya utama dan keputusan untuk menciptakan bisnis (Carr dan Sequeira, 2007; Pruett et al., 2009). Tak kalah pentingnya, pendapat teman dekat juga berperan penting sebagai penunjang relasional dan mempengaruhi keputusan individu untuk menjadi wirausaha. Pada gilirannya, meskipun pendapat rekan kerja tampaknya menempati posisi yang kurang relevan dibandingkan dengan keluarga dan teman dekat, penilaian mereka dalam hal kewirausahaan dapat mempengaruhi niat kewirausahaan individu (Nanda dan Sørensen, 2010).

Kaitan Closer Stigma of Entrepreneurial Failure (CSEF) dan Entrepreneurial Intentions (EI). Martins dan Perez (2019) menyatakan stigma kegagalan wirausaha, yang merupakan konsekuensi dari norma sosial, berimplikasi pada persepsi risiko pada tingkat aktivitas wirausaha. Dalam pengertian ini, semakin besar stigma yang dihasilkan oleh lingkungan dekat, semakin besar tekanan sosial yang didapat oleh mereka dan pengaruh sistematis dalam kesediaan individu untuk memulai usaha baru atau berpartisipasi dalam aktivitas yang melibatkan risiko (Armour dan Cumming, 2008; Simmons et al., 2014). Stigma sosial tentang kegagalan dapat menimbulkan persepsi negatif di kalangan pengusaha muda tentang kewirausahaan, dan persepsi ini memengaruhi perilaku individu sehingga membatasi niat mereka untuk melakukan usaha baru (Martins dan Perez, 2019).

Kaitan Individual Entrepreneurial Orientation (IEO) dan Entrepreneurial Intentions (EI). Pada dasarnya, entrepreneurial orientation adalah konstruksi satu dimensi yang tetap menjadi topik penelitian yang dinamis (Covin dan Wales, 2019). Beberapa penelitian telah mengkonfirmasi dan memvalidasi bahwa innovativeness, proactiveness dan risk taking adalah dimensi yang paling representatif dari konstruksi ini (Dai et al., 2014; Rauch et al., 2009; Robinson dan Stubberud, 2014). Di satu sisi, entrepreneurial orientation telah dijumpai secara luas dalam konteks organisasi, oleh karena itu, fokus utama diarahkan pada bisnis dan manajemen strategis (Rauch et al., 2009; Wales et al., 2013). Di sisi lain, organisasi dapat didefinisikan sebagai hasil dari perilaku individu (Bolton dan Lane, 2012; Robinson dan Stubberud, 2014); Oleh karena itu, entrepreneurial orientation dapat mengacu pada tingkat perusahaan atau individu. Kecenderungan individu terhadap kewirausahaan cenderung menghadirkan nilai-nilai yang terkait dengan innovativeness, proactiveness dan risk taking secara bersamaan (Goktan dan Gupta, 2015).

Kaitan Closer Valuation of Entrepreneurship (CVE) dan Individual Entrepreneurial Orientation (IEO). Interaksi antara individu dan lingkungan sosialnya memainkan peran penting dalam perkembangan IE (Gieure et al., 2019; Linan et al., 2011a). Sejauh lingkungan sosial yang dekat dengan individu (yaitu kelompok referensi) memiliki persepsi positif atau negatif tentang kewirausahaan, IE individu akan terpengaruh (Engle et al., 2010; Linan et al., 2011b; Santos et al., 2016). Kelompok referensi mempengaruhi perilaku individu, pengaruh ini melalui risk taking, innovativeness dan proactiveness, akhirnya dapat tercermin dalam niat individu untuk melakukan bisnis baru. Seperti yang disoroti dalam penelitian sebelumnya, individu yang berorientasi kewirausahaan cenderung memiliki skema mental yang berbeda dibandingkan dengan mereka yang tidak, dan bukti empiris menunjukkan bahwa individu wirausaha menunjukkan ciri kepribadian dan psikologi yang dapat dibedakan yang mempengaruhi pengambilan keputusan mereka (Gupta et al., 2016). 
Kaitan Closer Valuation of Entrepreneurship (CVE) dan Entrepreneurial Intentions (EI) dimediasi oleh Individual Entrepreneurial Orientation (IEO). Menurut Marques et al. (2013) karakteristik kognitif dan psikologis wirausaha mempengaruhi motivasi terhadap perilaku wirausaha serta atribut pribadi, seperti inovasi dan kecenderungan mengambil risiko, membuat individu lebih rentan terhadap aktivitas wirausaha. Orientasi terhadap perilaku kewirausahaan dapat memberikan dasar untuk keputusan dan tindakan kewirausahaan, oleh karena itu, dapat mempengaruhi keyakinan individu untuk mengidentifikasi dan mengembangkan ide bisnis dalam konteks di mana pendapat lingkungan sosial yang dekat campur tangan. Dengan kata lain, individu dengan kemampuan berinovasi lebih percaya diri dalam mencapai kesuksesan ide-idenya (Martins dan Perez, 2019).

Kaitan Closer Stigma of Entrepreneurial Failure (CSEF) dan Individual Entrepreneurial Orientation (IEO). Menurut Landier (2006) aktivitas kewirausahaan dapat dipengaruhi oleh rasa takut gagal tidak hanya dalam keputusan untuk mendirikan bisnis, tetapi juga dalam pemilihan usaha dan keputusan untuk melaksanakannya, dimana stigma yang terkait dengan kegagalan menjadi penentu penting dalam berwirausaha. Dalam penelitian kewirausahaan, ketakutan akan kegagalan telah diteliti dari segi ekonomi dan psikologi, menyoroti dampak negatif pada keputusan kewirausahaan (Cacciotti et al., 2016). Martins et al. (2018) mengatakan bahwa penghindaran risiko dapat mendominasi keputusan individu dan persepsi takut gagal adalah penentu dalam kaitannya dengan risiko yang terlibat dalam memulai proyek baru, persepsi risiko yang lebih rendah akan meningkatkan kemungkinan untuk memulai usaha (Cacciotti et al., 2016).

Kaitan Closer Stigma of Entrepreneurial Failure (CSEF) dan Entrepreneurial Intentions (EI) dimediasi oleh Individual Entrepreneurial Orientation (IEO). Persepsi masyarakat tentang kegagalan memiliki banyak implikasi untuk persepsi risiko dan tingkat aktivitas kewirausahaan dalam masyarakat tersebut (Baumol, 1993). Seperti yang diakatakan oleh Martins dan Perez (2019) bahwa stigma sosial tentang kegagalan dapat menimbulkan persepsi negatif di kalangan pengusaha muda tentang kewirausahaan, dan persepsi ini memengaruhi perilaku individu sehingga membatasi niat mereka untuk melakukan usaha baru.

Disamping dari stigma kegagalan, ditemukan bahwa individu yang kreatif dan inovatif akan lebih peka terhadap peluang wirausaha dan lebih rentan terhadap niat wirausaha (Gurel et al., 2010; Marques et al., 2013).

Berdasarkan uraian diatas, maka dapat disimpulkan kerangka pemikiran berikut ini:

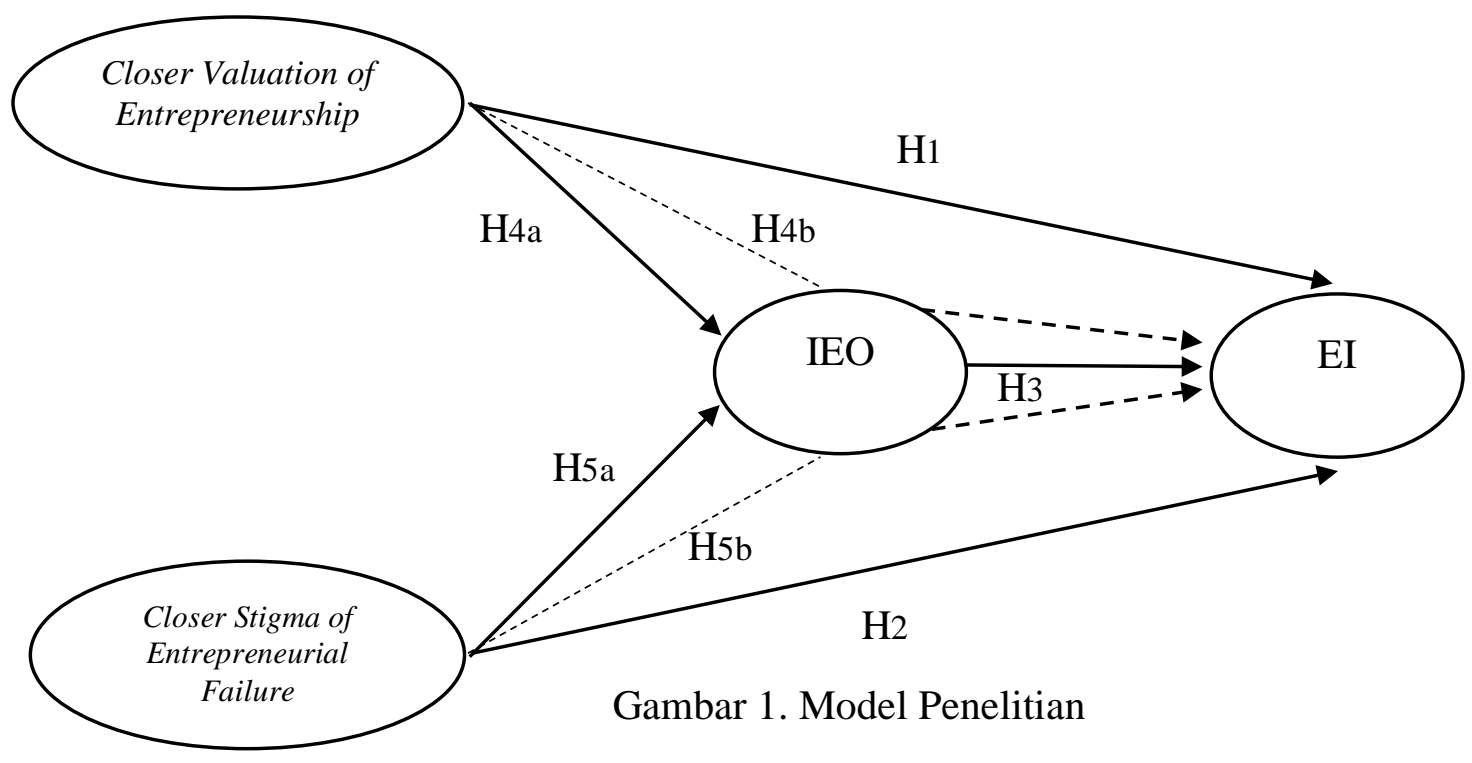


Berdasarkan penjelasan pada pengaruh variabel dan kerangka penelitian maka dapat ditentukan hipotesis penelitian sebagai berikut:

H1: Closer Valuation of Entrepreneurship berpengaruh terhadap Entrepreneurial Intentions Mahasiswa Fakultas Ekonomi dan Bisnis Universitas Tarumanagara.

H2: Closer Stigma of Entrepreneurial Failure berpengaruh terhadap Entrepreneurial Intentions Mahasiswa Fakultas Ekonomi dan Bisnis Universitas Tarumanagara.

H3: Individual Entrepreneurial Orientation berpengaruh terhadap Entrepreneurial Intentions Mahasiswa Fakultas Ekonomi dan Bisnis Universitas Tarumanagara.

H4a: Closer Valuation of Entrepreneurship berpengaruh terhadap Individual Entrepreneurial Orientation Mahasiswa Fakultas Ekonomi dan Bisnis Universitas Tarumanagara.

H4b: Closer Valuation of Entrepreneurship berpengaruh terhadap Entrepreneurial Intentions Mahasiswa Fakultas Ekonomi dan Bisnis Universitas Tarumanagara dimediasi oleh Individual Entrepreneurial Orientation.

H5a: Closer Stigma of Entrepreneurial Failure berpengaruh terhadap Individual Entrepreneurial Orientation Mahasiswa Fakultas Ekonomi dan Bisnis Universitas Tarumanagara.

H5b: Closer Stigma of Entrepreneurial Failure berpengaruh terhadap Entrepreneurial Intentions Mahasiswa Fakultas Ekonomi dan Bisnis Universitas Tarumanagara dimediasi oleh Individual Entrepreneurial Orientation.

\section{METODOLOGI}

Penelitian ini dilakukan kepada mahasiswa/i aktif program studi S1 manajemen di Fakultas Ekonomi dan Bisnis Universitas Tarumanagara pada tahun 2020. Penelitian ini melibatkan 126 responden dimana hanya 121 responden yang sudah mengambil mata kuliah kewirausahaan. Penelitian ini menggunakan metode penelitian kuantitatif deskriptif dan menggunakan teknik non-probability sampling dan purposive sampling. Selanjutnya hubungan antar variabel dianalisis dengan menggunakan metode analisis SEM-PLS dengan menggunakan aplikasi SmartPLS 3.3.2.

Penelitian ini menggunakan satu variabel dependen, dua variabel independen dan satu variabel mediasi. Variabel dependen yaitu Entrepreneurial Intentions, variabel independen yaitu Closer Valuation of Entrepreneurship dan Closer Stigma of Entrepreneurial Failure, dan variabel mediasi yaitu Individual Entrepreneurial Orientation. Berikut variabel dan indikator pada penelitian ini:

Tabel 1

Variabel dan Indikator Penelitian

\begin{tabular}{|c|c|c|}
\hline Variabel & Indikator & Kode \\
\hline \multirow{3}{*}{$\begin{array}{c}\text { Closer Valuation } \\
\text { of } \\
\text { Entrepreneurship }\end{array}$} & $\begin{array}{l}\text { Keluarga dekat saya lebih menghargai aktivitas sebagai wirausahawan } \\
\text { dibandingkan aktivitas dan karier lainnya }\end{array}$ & CVE1 \\
\hline & $\begin{array}{l}\text { Teman-teman saya lebih menghargai aktivitas sebagai wirausahawan } \\
\text { daripada aktivitas dan karier lainnya }\end{array}$ & CVE2 \\
\hline & $\begin{array}{l}\text { Kolega saya menghargai aktivitas sebagai wirausahawan dibandingkan } \\
\text { aktivitas dan karier lainnya }\end{array}$ & CVE3 \\
\hline \multirow{3}{*}{$\begin{array}{c}\text { Closer Stigma of } \\
\text { Entrepreneurial } \\
\text { Failure }\end{array}$} & $\begin{array}{l}\text { Stigma kegagalan kewirausahaan dari keluarga saya sangat penting } \\
\text { bagi saya }\end{array}$ & CSEF1 \\
\hline & $\begin{array}{l}\text { Stigma kegagalan kewirausahaan dari teman-teman saya sangat } \\
\text { penting bagi saya }\end{array}$ & CSEF2 \\
\hline & $\begin{array}{l}\text { Stigma kegagalan kewirausahaan dari rekan-rekan saya sangat penting } \\
\text { bagi saya }\end{array}$ & CSEF3 \\
\hline $\begin{array}{c}\text { Individual } \\
\text { Entrepreneurial }\end{array}$ & $\begin{array}{l}\text { Saya suka mengambil tindakan berani dengan menjelajahi hal yang } \\
\text { baru }\end{array}$ & EO1 \\
\hline
\end{tabular}




\begin{tabular}{|c|c|c|}
\hline \multirow[t]{9}{*}{ Orientation } & $\begin{array}{l}\text { Saya bersedia menginvestasikan banyak waktu dan/atau uang pada } \\
\text { sesuatu yang mungkin menghasilkan keuntungan yang tinggi }\end{array}$ & IEO2 \\
\hline & Saya cenderung bertindak "berani" dalam situasi berisiko & IEO3 \\
\hline & $\begin{array}{l}\text { Saya ingin mencoba aktivitas baru dan tidak biasa tetapi belum tentu } \\
\text { berisiko }\end{array}$ & IEO4 \\
\hline & $\begin{array}{l}\text { Saya lebih suka ditekan untuk proyek baru yang unik dengan } \\
\text { pendekatan yang berbeda daripada pendekatan yang telah digunakan } \\
\text { sebelumnya }\end{array}$ & IEO5 \\
\hline & $\begin{array}{l}\text { Saya lebih suka mencoba cara unik saya sendiri saat mempelajari hal- } \\
\text { hal baru daripada menggunakan cara yang umum }\end{array}$ & IEO6 \\
\hline & $\begin{array}{l}\text { Saya lebih menyukai percobaan dan cara saya sendiri untuk } \\
\text { memecahkan masalah daripada menggunakan metode yang umumnya } \\
\text { digunakan orang lain untuk memecahkan masalah mereka }\end{array}$ & IEO7 \\
\hline & Saya cenderung merencanakan proyek untuk masa depan & IEO8 \\
\hline & $\begin{array}{l}\text { Saya biasanya bertindak untuk mengantisipasi masalah, kebutuhan, } \\
\text { atau perubahan di masa depan }\end{array}$ & IEO9 \\
\hline & $\begin{array}{l}\text { Saya lebih suka melangkah dan menyelesaikan proyek daripada duduk } \\
\text { dan menunggu orang lain melakukannya }\end{array}$ & IEO10 \\
\hline \multirow{7}{*}{$\begin{array}{l}\text { Entrepreneurial } \\
\text { Intentions }\end{array}$} & Saya siap melakukan apapun untuk menjadi pengusaha & EI1 \\
\hline & Tujuan saya adalah menjadi seorang pengusaha & EI2 \\
\hline & $\begin{array}{l}\text { Saya akan berusaha semaksimal mungkin untuk memulai dan } \\
\text { menjalankan usaha saya sendiri }\end{array}$ & EI3 \\
\hline & Saya bertekad untuk membuat usaha di masa depan & EI4 \\
\hline & Saya sangat serius memikirkan untuk memulai sebuah perusahaan & EI5 \\
\hline & Saya memiliki niat yang kuat untuk memulai usaha suatu hari nanti & EI6 \\
\hline & $\begin{array}{l}\text { Saya bersedia menginvestasikan tabungan saya untuk memiliki usaha } \\
\text { saya sendiri }\end{array}$ & EI7 \\
\hline
\end{tabular}

Sumber: Martins dan Perez (2019)

\section{HASIL ANALISIS DATA}

Penelitian ini telah melakukan pengujian loading factors, cross loading, koefisien determinasi $\left(\mathrm{R}^{2}\right)$, pengukuran $\mathrm{Q}^{2}$ dan goodness of fit secara terpisah dari jurnal ini. Hasil pengujian loading factors dan cross loading, memperlihatkan bahwa indikator yang digunakan pada penelitian ini telah memenuhi syarat untuk digunakan didalam penelitian, yakni nilai loading factors diatas 0.7 dan cross loadings setiap indikator memiliki nilai yang lebih besar apabila dibandingkan dengan variabel lain.

Berdasarkan hasil pengujian $\mathrm{R}^{2}$ dalam penelitian ini, memperlihatkan bahwa variabel closer valuation of entrepreneurship, closer stigma of entrepreneurial failure dan individual entrepreneurial orientation memiliki pengaruh yang kuat terhadap variabel entrepreneurial intentions karena menghasilkan nilai $\mathrm{R}^{2}$ sebesar 0,742 . Hasil pengujian $\mathrm{Q}^{2}$ dalam penelitian ini, memperlihatkan bahwa variabel closer valuation of entrepreneurship, closer stigma of entrepreneurial failure dan individual entrepreneurial orientation memliki pengaruh yang kuat sebesar 0.551 terhadap variabel entrepreneurial intentions. Hasil pengujian Goodness of Fit (GoF) dalam penelitian ini, memperlihatkan bahwa model yang digunakan dalam penelitian ini memiliki kecocokan yang tergolong besar karena lebih dari 0.36, dengan hasil sebesar 0.5519.

Uji validitas pada penelitian ini dilihat dari nilai Average Variance Extracted (AVE) yang harus lebih besar dari 0.5, dan uji validitas dilihat dari hasil nilai Cronbach's Alpha yang harus lebih besar dari 0.7 dan Composite Reliability yang harus lebih besar dari 0.7. Berikut ini adalah hasil dari uji validitas dan reliabilitas penelitian ini: 
Tabel 2

Hasil Uji Validitas dan Reliabilitas

\begin{tabular}{|l|c|c|c|}
\hline \multicolumn{1}{|c|}{ Variabel } & $\begin{array}{c}\text { Average Variance } \\
\text { Extracted (AVE) }\end{array}$ & $\begin{array}{c}\text { Cronbach's } \\
\text { alpha }\end{array}$ & $\begin{array}{c}\text { Composite } \\
\text { Reliability }\end{array}$ \\
\hline Closer Valuation of Entrepreneurship & 0.830 & 0.898 & 0.936 \\
\hline Closer Stigma of Entrepreneurial Failure & 0.799 & 0.874 & 0.923 \\
\hline Individual Entrepreneurial Orientation & 0.779 & 0.952 & 0.961 \\
\hline Entrepreneurial Intentions & 0.671 & 0.945 & 0.953 \\
\hline
\end{tabular}

Sumber: Hasil Olah Data SmartPLS versi 3.3.2

Berdasarkan hasil pada tabel 2 diatas, dapat disimpulkan bahwa variabel yang digunakan pada penelitian ini telah memenuhi syarat validitas dan reliabilitas. Dapat disimpulkan bahwa variabel pada penelitian ini telah valid dan reliabel. Berikut ini akan disajikan hasil uji hipotesis (path coefficients) pada Tabel 3.

Tabel 3

Hasil Uji Hipotesis (Path Coefficients)

\begin{tabular}{|c|c|c|c|c|}
\hline & Hipotesis & T-statistic & P-value & Kesimpulan \\
\hline H1 & $\begin{array}{l}\text { Closer Valuation of Entrepreneurship } \rightarrow \\
\text { Entrepreneurial Intentions }\end{array}$ & 3.387 & 0.001 & Diterima \\
\hline H2 & $\begin{array}{l}\text { Closer Stigma of Entrepreneurial Failure } \rightarrow \\
\text { Entrepreneurial Intentions }\end{array}$ & 1.483 & 0.139 & Ditolak \\
\hline H3 & $\begin{array}{l}\text { Individual Entrepreneurial Orientation } \rightarrow \\
\text { Entrepreneurial Intentions }\end{array}$ & 4.248 & 0.000 & Diterima \\
\hline H4a & $\begin{array}{l}\text { Closer Valuation of Entrepreneurship } \rightarrow \\
\text { Individual Entrepreneurial Orientation }\end{array}$ & 4.937 & 0.000 & Diterima \\
\hline H4b & $\begin{array}{l}\text { Closer Valuation of Entrepreneurship } \rightarrow \\
\text { Entrepreneurial Intentions dimediasi Individual } \\
\text { Entrepreneurial Orientation }\end{array}$ & 2.899 & 0.002 & Diterima \\
\hline H5a & $\begin{array}{l}\text { Closer Stigma of Entrepreneurial Failure } \rightarrow \\
\text { Individual Entrepreneurial Orientation }\end{array}$ & 3.919 & 0.000 & Diterima \\
\hline H5b & $\begin{array}{l}\text { Closer Stigma of Entrepreneurial Failure } \rightarrow \\
\text { Entrepreneurial Intentions dimediasi Individual } \\
\text { Entrepreneurial Orientation }\end{array}$ & 3.166 & 0.002 & Diterima \\
\hline
\end{tabular}

Sumber: Hasil Olah Data SmartPLS versi 3.3.2

\section{DISKUSI}

Hasil penelitian menunjukkan bahwa pendapat keluarga, teman dan kolega mempengaruhi keputusan individu untuk menjadi pengusaha. Oleh karena itu, penilaian kewirausahaan yang lebih dekat oleh kelompok referensi berdampak positif pada entrepreneurial intentions individu. Hasil tersebut diperkuat dengan temuan sebelumnya yang menunjukkan peran utama keluarga, teman dekat dan kolega dalam hal pengaruh terhadap keputusan kaum muda untuk menjadi wirausaha (Ambad dan Damit, 2016; Nanda dan Sørensen, 2010; Pruett et al., 2009).

Terlepas dari kenyataan bahwa individu dengan individual entrepreneurial orientation tinggi tidak selalu memiliki niat nyata untuk menciptakan bisnis mereka sendiri (Thompson, 2009), mereka memandang dukungan dari lingkaran sosial dekat dengan cara yang lebih baik 
dan lebih toleran terhadap kemungkinan stigma wirausaha yang lebih dekat. kegagalan. Dengan kata lain, individual entrepreneurial orientation membentuk hubungan antara faktor lingkungan yang erat dan entrepreneurial intentions mahasiswa. Dengan mempertimbangkan inovasi siswa, ini dapat dipahami sebagai pendorong entrepreneurial intentions karena individu lebih yakin tentang kemungkinan keberhasilan ide bisnisnya dan percaya bahwa produk atau jasanya cenderung tidak gagal jika memiliki tingkat inovasi untuk industri. Proaktif siswa juga dapat menjadi komponen penting yang diperlukan untuk dimulainya kembali jika terjadi kegagalan kewirausahaan.

Akhirnya, fakta bahwa individual entrepreneurial orientation bertindak sebagai konstruksi mediasi kritis menunjukkan bahwa dalam kasus individu dengan tingkat inovasi, proaktif dan kecenderungan mengambil risiko yang tinggi, dampak dari pendapat kelompok referensi tentang kegagalan usaha menjadi kurang ditekankan. Penemuan ini memperkuat gagasan bahwa individu dengan individual entrepreneurial orientation tinggi adalah orang yang mandiri, bertekad, dan lebih percaya diri pada kemampuannya; oleh karena itu, individuindividu ini memiliki keyakinan yang lebih besar untuk menjalankan bisnis baru (Bolton dan Lane, 2012).

Penelitian ini tidak menemukan adanya pengaruh stigma kegagalan kewirausahaan dari keluarga, teman dan kolega pada keputusan individu untuk menjadi pengusaha, berbeda dari temuan sebelumnya (Martins dan Perez, 2019) yang menemukan bahwa stigma kegagalan yang diberikan dilingkungan dekat individu berpengaruh terhadap keputusan individu untuk menjadi pengusaha.

\section{PENUTUP}

Berdasarkan hasil pengujian yang telah dijabarkan sebelumnya, maka dapat disimpulkan bahwa:

a. Terdapat hubungan antara Closer Valuation of Entrepreneurship dengan Entrepreneurial Intentions Mahasiswa Fakultas Ekonomi dan Bisnis Universitas Tarumanagara Jakarta.

b. Tidak terdapat hubungan antara Closer Stigma of Entrepreneurial Failure dengan Entrepreneurial Intentions Mahasiswa Fakultas Ekonomi dan Bisnis Universitas Tarumanagara Jakarta.

c. Terdapat hubungan antara Individual Entrepreneurial Orientation dengan Entrepreneurial Intentions Mahasiswa Fakultas Ekonomi dan Bisnis Universitas Tarumanagara Jakarta.

d. Terdapat hubungan antara Closer Valuation of Entrepreneurship dengan Individual Entrepreneurial Orientation Mahasiswa Fakultas Ekonomi dan Bisnis Universitas Tarumanagara Jakarta.

e. Terdapat hubungan antara Closer Valuation of Entrepreneurship dengan Entrepreneurial Intentions Mahasiswa Fakultas Ekonomi dan Bisnis Universitas Tarumanagara Jakarta melalui Individual Entrepreneurial Orientation.

f. Terdapat hubungan antara Closer Stigma of Entrepreneurial Failure dengan Individual Entrepreneurial Orientation Mahasiswa Fakultas Ekonomi dan Bisnis Universitas Tarumanagara Jakarta.

g. Terdapat hubungan antara Closer Stigma of Entrepreneurial Failure dengan Entrepreneurial Intentions Mahasiswa Fakultas Ekonomi dan Bisnis Universitas Tarumanagara Jakarta melalui Individual Entrepreneurial Orientation.

Berdasarkan kesimpulan diatas, maka peneliti dapat memberikan saran sebagai berikut:

a. Bagi mahasiswa, diharapkan dapat termotivasi dalam membuat suatu usaha dimasa yang akan datang dan membuat lapangan kerja baru bagi orang lain.

b. Bagi calon wirausaha, diharapkan dapat menemukan dan belajar hal-hal baru yang belum pernah ditemukan sebelumnya dalam membuat suatu usaha sehingga dapat membuat usaha yang baik. 
c. Bagi calon wirausaha, diharapkan dapat berani mengambil keputusan dalam membuat suatu usaha.

\section{DAFTAR PUSTAKA}

Ajzen, I. (1991). The Theory of Planned Behavior. Organizational Behavior and Human Decision Processes 50, 179-211.

Ambad, S. N., \& Damit, D. H. (2016). Determinants of Entrepreneurial Intention among Undergraduate Students in Malaysia. Procedia Economics and Finance 37 , 108-114.

Armour, J., \& Cumming, D. (2008). Bankruptcy Law and Entrepreneurship. Working Paper $N^{\circ} .105$.

Bolton, D. L., \& Lane, M. D. (2012). Individual Entrepreneurial Orientation: Development Of A Measurement Instrument.

Cacciotti, G., Hayton, J. C., Mitchell, J. R., \& Giazitzoglu, A. (2016). A Reconceptualization Of Fear Of Failure In Entrepreneurship. ournal of Business Venturing, 31, 302-325.

Carr, J. C., \& Sequeira, J. M. (2007). Prior Family Business Exposure As Intergenerational Influence and Entrepreneurial Intent: A Theory of Planned Behavior Approach. Journal of Business Research 60 , $1090-1098$.

Covin, J. G., \& Wales, W. J. (2019). Crafting High-Impact Entrepreneurial Orientation Research: Some Suggested Guidelines. Entrepreneurship Theory and Practice vol.43(I), 3-18.

Dai, L., Maskimov, V., Gilbert, B. A., \& Fernhaber, S. A. (2014). Entrepreneurial Orientation And International Scope: The Differential Roles Of Innovativeness, Proactiveness, And Risk-Taking. Scholarship and Professional Work - Business.

Dewi, N. P., \& Nurcaya, I. N. (2017). Niat Berwirausaha Di Kalangan Mahasiswa Fakultas Ekonomi Dan Bisnis Universitas Udayana Dan Universitas Warmadewa. E-Jurnal Manajemen Unud, Vol. 6, No. 4, 2191-2221.

Engle, R. L., Dimitriadi, N., Gavidia, J. V., Schlaegel, C., Delanoe, S., Alvarado, I., . . Wolff, B. (2010). Entrepreneurial Intent A Twelve-Country Evaluation Of Ajzen's Model Of Planned Behaviour.

Gieure, C., Benavides-Espinosa, M. d., \& Roig-Dobón, S. (2019). Entrepreneurial Intentions In An International University Environment.

Goktan, A. B., \& Gupta, V. K. (2015). Sex, Gender, And Individual Entrepreneurial Orientation: Evidence From Four Countries. International Entrepreneurship Management Journal 11, 95-112.

Gupta, V. K., Niranjan, S., Goktan, B. A., \& Eriskon, J. (2016). Individual Entrepreneurial Orientation Role In Shaping Reactions To New Technologies. International Entrepreneurship Management Journal 12, 935-961.

Gurel, E., Altinay, L., \& Daniele, R. (2010). Tourism Students' Entrepreneurial Intentions. Annals of Tourism Research, Vol. 37 No. 3, 646-669.

Iakovleva, T., Kolvereid, L., \& Stephan, U. (2011). Entrepreneurial Intentions in Developing and Developed Countries. Education + Training Vol.53 No.5, 353-370.

J.Baumol, W. (1993). Formal Entrepreneurship Theory In Economics: Existence And Bounds. Journal of Business Venturing Vol.8 Issue 3, 197-210.

Koe, W.-L. (2016). The Relationship Between Individual Entrepreneurial Orientation (IEO) And Entrepreneurial Intention. Journal of Global Entrepreneurship Research, 6-13.

Landier, A. (2006). Entrepreneurship And The Stigma Of Failure.

Liñán, F., D. U., \& Guerrero, M. (2011b). Regional Variations in Entrepreneurial Cognitions: Start-Up Intentions of University Students in Spain. 
Liñán, F., Santos, F. J., \& Fernández, J. (2011a). The Influence Of Perceptions On Potential Entrepreneurs. International Entrepreneurship Management Journal 7, 373-390.

Marques, C. S., Ferreira, J. J., Ferreira, F. A., \& Lages, M. F. (2013). Entrepreneurial Orientation And Motivation To Start Up A Business: Evidence From The Health Service Industry. International Entrepreneurship and Management Journal vol.9(1), 77-94.

Martins, I., \& Perez, J. P. (2019). Testing Mediating Effects Of Individual Entrepreneurial Orientation On The Relation Between Close Environmental Factors And Entrepreneurial Intention.

Martins, I., Monsalve, J. P., \& Martinez, A. V. (2018). Self-confidence And Fear Of Failure Among University Students And Their Relationship With Entrepreneurial Orientation: Evidence From Colombia.

Nanda, R., \& Sørensen, J. B. (2010). Workplace Peers and Entrepreneurship.

Pruett, M., Shinnar, R., Toney, B., Llopis, F., \& Fox, J. (2009). Explaining Entrepreneurial Intentions Of University Students: A Cross-Cultural Study.

Rauch, A., Wiklund, J., Lumpkin, G. T., \& Frese, M. (2009). Entrepreneurial Orientation And Business Performance: An Assessment Of Past Research And Suggestions For The Future. Entrepreneurship Theory and Practice.

Robinson, S., \& Stubberud, H. A. (2014). Elements Of Entrepreneurial Orientation And Their Relationship To Entrepreneurial Intent. Journal of Entrepreneurship Education Vol.17 No. 2.

Santos, F. J., Roomi, M. A., \& Liñán, F. (2016). About Gender Differences and the Social Environment in the Development of Entrepreneurial Intentions. Journal of Small Business Management 54(1), 49-66.

Shapero, A., \& Sokol, L. (1982). The social dimensions of entrepreneurship. Encyclopedia of entrepreneurship, 72-90.

Simmons, S. A., Wiklund, J., \& Levie, J. (2014). Stigma and Business Failure: Implications For Entrepreneurs' Career Choices. Small Business Economics 42, 485-505.

Sumadi, A. R., \& Sulistyawati, E. (2017). Pengaruh Sikap, Motivasi, Dan Lingkungan Terhadap Niat Berwirausaha. E-Jurnal Manajemen Unud Vol.6 No.2, 1007-1029.

Thompson, E. R. (2009). Individual Entrepreneurial Intent: Construct Clarification and Development of an Internationally Reliable Metric.

Wales, W. J., Gupta, V. K., \& Mousa, F.-T. (2013). Empirical Research On Entrepreneurial Orientation: An Assessment And Suggestions For Future Research. International Small Business Journal 31(4), 357 -383. 